\title{
Accessibility to primary health care in low-density regions. A case study: NUTS III - Baixo Alentejo - Portugal
}

\author{
A acessibilidade aos cuidados de saúde primários em regiões de baixa \\ densidade. Caso de estudo: NUTS III - Baixo Alentejo - Portugal
}

Carlos Freitas (https://orcid.org/0000-0003-0689-137X) ${ }^{1}$

Nuno Marques da Costa (https://orcid.org/0000-0003-4859-9668) ${ }^{1}$

${ }^{1}$ Centro de Estudos Geográficos, Instituto de Geografia e Ordenamento do Território (IGOT), Universidade de Lisboa. Edifício IGOT, Rua Branca Edmée Marques. 1600-276 Lisboa Portugal. carlosfreitas@campus.ul.pt

\begin{abstract}
This study diagnosed the situation regarding the physical accessibility of the resident population to primary health care, based on the characteristics of the population served, their spatial distribution in the territory, based on spacetime analysis. Thus, bearing the different means of transport available and the specific features of a low-density territory, we considered several mobility profiles under analysis, and selected the Baixo Alentejo as the study area. In methodological terms, besides using the location of primary health facilities and their areas of influence, the use of the road network and its restrictions, we selected the use the new $1 \times 1 \mathrm{~km}$ grid, recently implemented throughout the EU (European Union), instead of using the statistical units or administrative boundaries. Its advantages allow overcoming some of the issues of the usual base cartography. The final results can be divided into two groups: conclusions related to the methodologies used and conclusions related to the accessibility of primary health care equipment in the study area.
\end{abstract}

Key words Accessibility, Primary health care equipment, Low-population-density territories, 1 $\mathrm{km}^{2}$ grid
Resumo Decidiu-se realizar o diagnóstico de situação sobre a acessibilidade física da população residente aos cuidados de saúde primários, baseada nas características da população servida, na sua distribuição espacial, tendo por base uma análise espaço/tempo, permitindo avaliar essa mesma acessibilidade. Deste modo, e tendo em consideração os diversos modos de transporte disponiveis, bem como as características específicas de um território de baixa densidade, foram considerados diversos perfis de mobilidade, sendo a área de estudo escolhida o Baixo Alentejo. Em termos metodológicos, além da utilização da localização dos equipamentos de saúde primários $e$ das suas áreas de influência, da utilização da rede viária e das suas restrições, optou-se pela utilização de uma cartografia base menos convencional. Em vez das unidades estatísticas associadas às unidades administrativas, optou-se pela utilização da nova quadrícula de $1 \times 1 \mathrm{~km}$, implementada recentemente em toda a União Europeia (UE). A utilização desta quadrícula permite ultrapassar alguns dos problemas apresentados pela cartografia base habitual. Os resultados podem-se dividir em dois grupos: conclusões relacionadas com as metodologias utilizadas, e conclusões relacionadas com a acessibilidade aos equipamentos de saúde primários na área de estudo.

Palavras-chave Acessibilidade, Equipamentos de saúde primários, Territórios de baixa densidade populacional, Quadrícula $1 \mathrm{~km}^{2}$ 


\section{Introduction}

The accessibility to primary health care has recently been the target of high interest by the researchers in health geography. The World Health Organization has also expressed this interest since the end of the $20^{\text {th }}$ century, concerned with accessibility to health care, including one of the 28 goals equated in the "Global Strategy for Health for All by the Year 2000"'.

Also, the European Union (EU) stresses the need to improve accessibility to health care in each Member State as one of the prominent topics of the SeIG, since these are related to a set of public obligations that aim to ensure the provision of services to all citizens, following specific standards, responding to principles of economic, social and territorial fairness and standards that confer the feature of service of general interest quality and variety ${ }^{2}$.

In health geography, the most pertinent matters are related to issues such as inequalities in health care access, re-emergence of infectious diseases, health policies, and adequacy of health services to the local population ${ }^{3}$.

Health care access inequality is commonly assumed to arise from the accessibility conditions, namely accessibility to primary care services, hence the interest in analyzing the population accessibility conditions to this type of health services. Accessibility is a crucial concept in studies in transport and mobility, and, through GIS (geographic information systems), are increasingly used to measure the impacts of geographic accessibility. The capacity of GIS networks has gradually favored the implementation of the geographic in-depth analysis and allowed the incorporation of other relevant elements, such as calculating travel times and defining shortest routes to reach health services ${ }^{4}$. However, there is still no consensus on the standard measure to be used in the health geography and which of the principal methodologies has better results, namely, gravity-based model measures, measures of cumulative opportunities, and space-time measures.

In this work, we chose the one that seemed more consensual, and at the same time, with a more straightforward understanding and a more direct interpretation: space-time measurements. Space-time measurements are based on the temporal structure of Hägerstrand's space-time geography ${ }^{5}$, i.e., the space-temporal prism determines the feasible set of locations for the participation of travel and activities in a limited extent of space and time interval. A delimited space-temporal region is represented by an orthogonal triad of axes, with a pair of labeled axes ( $\mathrm{x}$ and $\mathrm{y}$ ) defining the two-dimensional plane space, and an axis representing time (z). A point object located in $x_{i}$ and $y_{i}$ shows the object's location coordinates in the two-dimensional space in time. However, as time progresses (i.e., positive movement along the $z$-axis), the object, usually representing an individual, becomes visible in its movement in space over time.

This three-dimensional perception conceives the activities of individuals and allows them to travel according to continuous trajectories or paths in the three-dimensional space-time. Those paths do not exist randomly in space-time but are subject to several personal or social restrictions, network features, mobility limitations resulting from available transport technology, and physical need for rest. In short, the distance has played so far one of the leading roles in shaping contemporary cities and human behavior according to traditional models. However, the approach through space-time measures goes beyond to overcome the limitations of the conceptual foundation and the spatial and temporal structures of traditional models ${ }^{6}$. This is when GIS are essential to this methodology's success because they allow the incorporation and model the complexities of the real world in unprecedented inconceivable ways and transcend simplifications used on traditional, proximity-based urban models and accessibility measures.

Thus, also having the theories based on spatial-temporal measures as starting point, we measured people's accessibility in NUTS III (Common statistical classification of territorial units) of Baixo Alentejo to the primary care equipment (PCE) network in the influence areas predefined by the National Health Service (SNS), regardless of medical valences, schedules or medical staff provided by primary care equipment.

Contrary to many studies using the method of determining access to health services that use the two-step floating catchment area method, in which competition between different equipment is assumed $\mathrm{d}^{7-9}$, we have an administrative definition of service in the national case areas of each PCE.

\section{Paper Organization}

This paper is essentially organized in three key points: 1) Modeling methods and techniques, where the concept of cartography in $1 \mathrm{~km}^{2}$ grid is highlighted instead of the traditional admin- 


\section{Modeling methods and techniques The $1 \mathrm{~km}^{2}$ grid}

The analysis results vary with size and scale of the statistical unit for data collection. In this case, we would aim to be as thorough as possible regarding the population location, namely in low-density areas and, at the same time, where statistical units cover large areas. Thus, the use of information on a classical administrative scale was not an option due to the error associated with the population allocation to polygons whose limits are associated with too large administrative areas for measuring the distance between the population and health centers. So, we opted for a less traditional approach, applying the kilometric grid, the geographical referential made available by the Statistics Portugal (Instituto Nacional de Estatística, INE) since 2013, as a result of GEOSTAT Project ${ }^{10}$. In its genesis, the GEOSTAT project includes the creation of a broad and harmonized dataset for the EU concerning the distribution and characterization of the population of the 2010/2011 census because, while there are common statistical units (NUTS), their size is not equivalent in a diversified $\mathrm{EU}$ with various administrative limits and different sizes. As such, the development of comparative studies between regions hardly uses comparable statistical data. In the Portuguese case, the grid was applied to information referring to the 2011 censuses, namely to the resident population, buildings, lodgings, and households, and the BGE (Geographic Base of Buildings).

Using the $1 \mathrm{~km}^{2}$ grid for statistical analysis has diverse strengths and weaknesses (Chart 1). The advantages associated with its use result from the possibility of carrying out comparative analyses between regions, which is not the case with administrative or statistical limits of very different dimensions. The information of each cell in the network is an index, since when its spatial unit has the same dimension, each variable is by nature a density and the spatial precision associated with the grid size, $1 \times 1 \mathrm{~km}$, is most of the time closer to reality. On the other hand, the significant drawbacks result from the difficulty in crossing this information with the information collected from the official administrative limits, since this crossing does not exist naturally.

Thus, since administrative boundaries rarely have a geometric shape defined as a grid, it has been decided that all the grids that are present in an edge area (which intersect with the administrative limits in question) must be analyzed separately. We considered a solution that is simple and effective to solve this problem with the edge areas, which translates into the following steps:

1) Identifying the edge grids cells by crossing the administrative limits with the limits of the cells in question;

2) Carrying out a weighted average in the hinge areas between the area belonging to the administrative area and the variable value associated with the grid cell.

The comparison of the administrative units' census values and the values obtained for the same areas from the $1 \mathrm{x} 1 \mathrm{~km}$ grid followed by the previous procedure were consistent, noting a mean error of $0.5 \%$. Given the low error value, we assumed to proceed with the grid information analysis for modeling accessibility.

\section{Areas of Influence (AI)}

Generally, the areas of influence are defined as a particular geographic area where most of the users of a particular service or business are concentrated, or most of the profits from a specific business are located, commonly from $60 \%$ to $80 \%$, since the remaining $20 \%-40 \%$ are considered as possible exceptions or outliers ${ }^{11}$. The PHC

Chart 1. SWOT analysis.

\begin{tabular}{|l|l|l|l|}
\hline \multicolumn{1}{|c|}{ Strengths } & \multicolumn{1}{c|}{ Weaknesses } & \multicolumn{1}{c|}{ Opportunities } & \multicolumn{1}{c|}{ Threats } \\
\hline Spatial accuracy & $\begin{array}{l}\text { Absence of administrative } \\
\text { boundaries }\end{array}$ & $\begin{array}{l}\text { Comparative analyses between } \\
\text { regions, even with distinct scales }\end{array}$ & $\begin{array}{l}\text { Limited data } \\
\text { available }\end{array}$ \\
\hline $\begin{array}{l}\text { The existing variables work } \\
\text { by themselves as indices }\end{array}$ & $\begin{array}{l}\text { Need to analyze the edge } \\
\text { grid units separately }\end{array}$ & $\begin{array}{l}\text { Freedom to find patterns that don't fit } \\
\text { the administrative boundaries }\end{array}$ & \\
\hline
\end{tabular}

Source: Author. 
equipment analyzed in this work is in a type of service that cannot be included in this definition.

In the case of health equipment and other cases such as education, the area of influence (AI) of this equipment has unique features, namely an area of influence defined by administrative regulation. In this case, the AI considers only the fixed limits defined by the SNS, i.e., its area of intervention does not depend on the influence of the good or service itself but is officially defined and not overlapping with any other. The entire territory must be obligatorily covered, and the population served by it must be served by one and only one AI. Thus, for the network's modeling concerning accessibility to PHC equipment, it is necessary to define the areas of influence of each equipment and measure the accessibility of the population to their health equipment.

Therefore, in this specific case, all PCEs in the study area were considered, in a total of 78 PCEs, and the parishes allocated to each PCEs by the SNS, confirming that there were no AIs overlapping and the entire study area was covered.

\section{Accessibility profiles for PCE}

A fundamental point in the study of population accessibility is the definition of accessibility profiles, which are defined according to the used transport mean, the people transported, and the network's constraints ${ }^{12}$. Thus, after an analysis of the road network, the transport network, and a socio-economic analysis of the population, the accessibility profiles chosen were:

Pedestrian profile 1: considers the pedestrian mobility of the population through the existing road network bearing the areas of influence. It does not consider the restrictions of the network for automobile circulation. The value of the mobility velocity attributed was $4.5 \mathrm{~km} / \mathrm{hour}$, an average adult walking speed ${ }^{13}$;

Pedestrian profile 2: due to the weight of the elderly population (over 65 years) in the totality of the population living in the study area, a specific profile was considered for this population cohort. It considers the pedestrian mobility of the population through the existing road network, bearing the areas of influence. It does not consider the restrictions of the network for the automobile circulation. The value of the assigned walking speed was $3.5 \mathrm{~km} /$ hour $^{14}$;

Bicycle profile: this profile considers only the distance to each equipment by the population through the existing road network, bearing the areas of influence. The value of the assigned mo- bility velocity was $16 \mathrm{~km} /$ hour $^{15}$. This profile was considered feasible based on the following principles: poor slopes; transport means traditionally used by the local population; more efficient and rational transport means for urban commuting (in order to the characteristics of the population and urban system in Baixo Alentejo);

Automotive vehicle: it considers the distance to each equipment by the population through the existing road network, bearing the areas of influence and the network constraints: maximum speeds allowed by the national road code by road type; traffic directions; and other network limitations ${ }^{16}$.

The time-distance profile in public transportation (whether urban or regional) was not considered in this study. The existence of public transport in most urban areas in our area of study is non-existent in most of the cases, and when available, the provision is scarce and very limited (at the level of operation time and bus frequency), for a viable and adequate alternative to the regular use of PCE.

Indeed, and according to Figueira de Sousa et al., "Public road transport operators (...) tend to adapt their offer to the evolution of rural demand and low urban density areas"17. Given the dynamics, in general, reducing the levels of service, watching the extinction of less demanding routes, or reducing frequencies and amplitude of service, have guided this adaptation. In these areas, the provision often comes down to one daily service on working days, which serves the settlements located along the main roads". Thus, the most viable alternative in terms of public transport would be taxis, and in exceptional cases, the use of school transport, although it is limited to student seat vacancy and the routes and schedules of this service. In turn, taxis are often the only transport option. However, the cost per trip and the waiting time end up discouraging its use, giving priority to car use, and when car is not available, to occasional services made available by the social care entities or local level authorities (parishes)" ${ }^{17}$.

\section{Study Area Framework}

Baixo Alentejo is one of the five NUTS III of NUTS II Alentejo and comprises 13 municipalities subdivided into 84 parishes. It has a total area of $8,542.7 \mathrm{~km}^{2}$ served by $3,085 \mathrm{~km}$ of roads, divided into several classes of roads, motorways (AE), main itineraries (IP), complementary itineraries (IC), national and municipal roads, and urban roads (Figure 1). 
Figure 1. NUTS III Framework.

Source: Own development.

The Baixo Alentejo is served by the railway that crosses Alvito, Cuba, and Beja and by intercity and intermunicipal road transport service, constrained by a low level of service. The Rede Expressos and the Rodoviária do Alentejo are the primary providers of these regional services. Urban transport (UT) is almost non-existent, limited to the UT of Beja with five routes and with limited schedules, the UT of Moura with one free circuit by the city's main points, but limited to Monday through Friday, from 08:00 to 12:00. The UT of Ourique has two urban routes and seven municipal routes, also with limited timetables and frequencies. All municipalities also have a school transport service that works according to the school calendar and serves only the municipality students.

In 2011, Baixo Alentejo had 126,692 inhabitants, distributed over a total of $8,543.5 \mathrm{~km}^{2}$, resulting in a low density of 14.8 inhabitants per $\mathrm{km}^{2}$ (Statistics Portugal, 2012).
Using the new grid for a more realistic interpretation of the population density distribution in the territory, and after analyzing it, we found that the territory of Baixo Alentejo has a total of $8,9151 \mathrm{~km}^{2}$ squares, of which $97 \%$ have a density below 50 inhabitants per $\mathrm{km}^{2}$. The exceptions (3\% of the territory) identify the few urban areas with the highest population concentration of the territory, with 145 squares between 50 and 199 inhabitants per $\mathrm{km}^{2}, 63$ squares between 200 and 499 inhabitants per $\mathrm{km}^{2}, 31$ squares between 500 and 1,000 inhabitants per $\mathrm{km}^{2}$, and 31 grid cells with more than 1,000 inhabitants per $\mathrm{km}^{2}$. On the other hand, it showed an aged population showed by a population pyramid of Baixo Alentejo with a regression pattern, without renewal, and with some hollow classes associated with a robust migratory movement of the active age population. 


\section{Results}

Based on predefined modeling rules per the characteristics of the road network and the speed profiles, the ArcGIS Network Analyst extension was used as incremental support, and the Model Builder was employed to automate the processing of the various areas of influence and accessibility profiles. It is also important to note that the time-distance matrix has been converted into a nominal scale to simplify the typology of accessibility. This nominal classification was based exclusively on the individual's perspective about distance and how far he/she is willing to walk for a good or service. Therefore, the classification is as follows: $[0-5]$ minutes = Excellent; [5-10] minutes $=$ Good; $[10-15]$ minutes $=$ Fair; $[15-30]$ minutes $=$ Weak and $>30$ minutes $=$ Poor .

The results were analyzed and aggregated, resulting in the following outcomes. Concerning the network distance to the PCE (Table 1), the Baixo Alentejo shows a territory with a predominance of areas with distances of 5-10 km and 10$25 \mathrm{~km}$. Regarding the population, $45.5 \%$ are less than $1 \mathrm{~km}$ away from the PCE, and $28.5 \%$ at a distance between 1 and $2 \mathrm{~km}$. Considering the area, only $6.2 \%$ of the territory is less than $2 \mathrm{~km}$ apart due to high population concentration. Concerning age groups, the prevailing distance of less than $1 \mathrm{~km}$ to a PCE is common to all, although in this case, it is slightly higher on the aged group.

Considering the pedestrian profile 1 (Figure 2 and Table 2), we find that a large part of the population $(48.55 \%)$ has poor or very poor accessibility (most are at a distance of more than 15 minutes to PCE and less than 30 minutes), while only $8.44 \%$ have excellent accessibility. There is no clear differentiation between age groups.
As pedestrian profile 2 (Figure 3 and table 3 ), most of the population (61.2\%) has poor or very poor accessibility (most are at a distance of more than 15 minutes to PCE and less than 30 minutes), while only $20.43 \%$ of the population has good accessibility (travel up to 10 minutes), and there is no clear differentiation between age groups.

Regarding the bicycle profile (Figure 4 and Table 2), it turns out that a large part of the population has excellent or good accessibility to their PCE $(79.8 \%)$. If the oldest age group has excellent accessibility for more than $60 \%$ of this group's population, we also verified that the value of poor accessibility, which is $9.9 \%$, is much higher than the other age groups.

According to the automotive profile that presupposes the car's use (Figure 5 and Table 3 ), most of the population (85.6\%) is less than 5 minutes away and $95.8 \%$ up to 10 minutes away from the respective PCE. Poor accessibility using the car is residual, but we verified that the oldest population has worse accessibility, with $2.7 \%$ more than 15 minutes away from its PCE.

\section{Conclusions}

The conclusions of the work can be divided into two groups: 1) results about to the methodologies used; 2) results relating to accessibility to PCE.

Regarding tested methodologies, it is essential to highlight the importance of using the $1 \times 1 \mathrm{~km}$ grid to create the models. This method allowed locating the population with greater accuracy and total concentration in the study territory, and improving the model and the calcu-

Table 1. Distance to PCE (AI according to SNS).

\begin{tabular}{|c|c|c|c|c|c|c|c|c|c|c|c|c|c|}
\hline \multirow{2}{*}{ Distance (m) } & \multicolumn{2}{|c|}{ Grid cells } & \multicolumn{3}{|c|}{ Area } & \multicolumn{4}{|c|}{ Population \% } & \multicolumn{4}{|c|}{ Population $\% \sum$} \\
\hline & $n^{o}$ & $\%$ & $\mathbf{k m}^{2}$ & $\%$ & $\% \sum$ & Total & $<15$ & {$[15-64]$} & $>64$ & Total & $<15$ & [15-64] & $>64$ \\
\hline 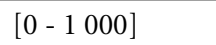 & 455 & 2.8 & 122.2 & 1.4 & 1.4 & 45.5 & 44.7 & 45.2 & 46.8 & 45.5 & 44.7 & 45.2 & 46.8 \\
\hline ]1 $000-2000]$ & 999 & 6.2 & 321.9 & 3.8 & 5.2 & 28.5 & 30.2 & 28.9 & 26.8 & 74.1 & 74.9 & 74.1 & 73.6 \\
\hline ]2 $000-5000]$ & 3218 & 20.1 & 1685.9 & 19.7 & 24.9 & 9.9 & 12.0 & 10.4 & 7.8 & 84.0 & 86.9 & 84.5 & 81.4 \\
\hline ]5 000 - 10000 ] & 5329 & 33.3 & 2945.8 & 34.5 & 59.4 & 10.3 & 9.3 & 10.4 & 10.7 & 94.3 & 96.2 & 94.9 & 92.0 \\
\hline ]10 000 - 25000 ] & 5042 & 31.5 & 2932.1 & 34.3 & 93.7 & 4.9 & 3.3 & 4.5 & 6.9 & 99.3 & 99.5 & 99.4 & 99.0 \\
\hline$>25000$ & 956 & 6.0 & 534.9 & 6.3 & 100.0 & 0.7 & 0.5 & 0.6 & 1.0 & 100.0 & 100.0 & 100.0 & 100.0 \\
\hline Total & 15999 & 100.0 & 8542.8 & 100.0 & & 100.0 & 100.0 & 100.0 & 100.0 & & & & \\
\hline
\end{tabular}

Source: Author. 


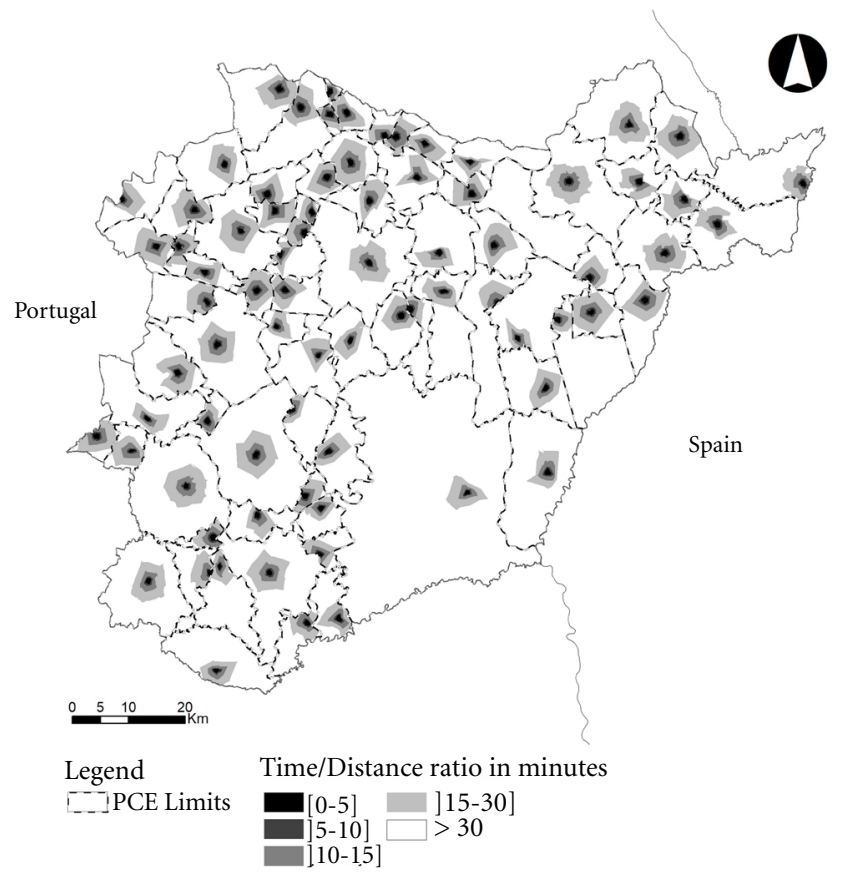

Figure 2 . Pedestrian profile 1.

Source: Author.

Table 2. Accessibility of the population to PCE (according to the AI defined by the SNS) on the pedestrian profile 1 , pedestrian profile 2 , and bicycle profile (\%).

\begin{tabular}{lrrrrrrrrrrrrr}
\hline \multirow{2}{*}{ Distance (min) } & \multicolumn{4}{c}{ Pedestrian profile 1 } & \multicolumn{4}{c}{ Pedestrian profile 2 } & \multicolumn{4}{c}{ Bicycle profile } \\
\cline { 2 - 13 } & Total & $<\mathbf{1 5}$ & {$[\mathbf{1 5 - 6 4}]$} & $>\mathbf{6 4}$ & Total & $<\mathbf{1 5}$ & {$[\mathbf{1 5 - 6 4}]$} & $>\mathbf{6 4}$ & Total & $<\mathbf{1 5}$ & {$[\mathbf{1 5 - 6 4}]$} & $>\mathbf{6 4}$ \\
\hline$[0-5]$ & 8.8 & 8.5 & 8.7 & 9.3 & 5.3 & 5.1 & 5.3 & 5.6 & 59.4 & 59.0 & 59.2 & 60.3 \\
]5-10] & 22.5 & 22.0 & 22.3 & 23.2 & 15.1 & 14.6 & 14.9 & 15.7 & 20.4 & 23.0 & 21.0 & 17.4 \\
] $10-15]$ & 20.1 & 20.2 & 20.1 & 20.1 & 18.4 & 18.2 & 18.3 & 18.6 & 3.1 & 3.8 & 3.2 & 2.6 \\
]15-30] & 25.6 & 27.6 & 26.1 & 23.3 & 31.2 & 32.4 & 31.3 & 30.2 & 9.5 & 8.9 & 9.6 & 9.8 \\
$>30$ & 22.9 & 21.6 & 22.8 & 24.3 & 30.0 & 29.6 & 30.1 & 29.8 & 7.5 & 5.3 & 7.0 & 9.9 \\
Total & 100.0 & 100.0 & 100.0 & 100.0 & 100.0 & 100.0 & 100.0 & 100.0 & 100.0 & 100.0 & 100.0 & 100.0 \\
\hline
\end{tabular}

Source: Author.

lation of the different distances according to the defined profiles. Using the grid for the administrative limits showed only one limitation, which was already expected: the error associated with the total values of the population covered by the grid compared with the values associated with the administrative limits. This error was overcome by applying a simple weighted average of the population values with the area of the respective administrative limit, resulting in a difference of values of around $0.5 \%$, which was considered acceptable given the shown advantages.

Considering the accessibility of the population to their PCE in Baixo Alentejo presented in the results of this study, about half of the population has "weak" or "poor" accessibility for walking, a situation that is aggravated when considering a reduced walking speed (pedestrian profile 2 ), where the value exceeds $60 \%$. In contrast, just under a third of the population has "good" 


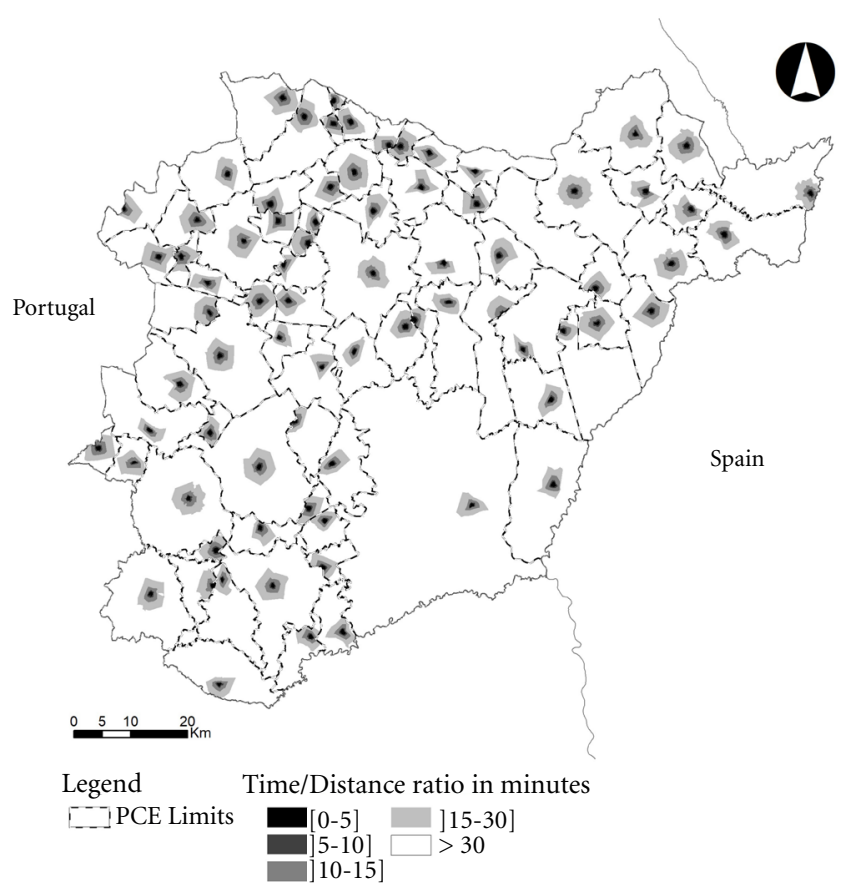

Figure 3. Pedestrian profile 2.

Source: Own development.

Table 3. Accessibility of the population to PCE (according to the AI defined by the SNS), on the automotive profile (\%).

\begin{tabular}{lrrrr}
\hline \multirow{2}{*}{ Distance (min) } & \multicolumn{4}{c}{ automotive profile } \\
\cline { 2 - 5 } & Total & $<\mathbf{1 5}$ & {$[\mathbf{1 5}-\mathbf{6 4}]$} & $>\mathbf{6 4}$ \\
\hline$[0-5]$ & 85.6 & 88.3 & 86.1 & 83.2 \\
{$[5-10]$} & 10.2 & 8.9 & 10.2 & 10.9 \\
] $10-15]$ & 2.3 & 1.5 & 2.1 & 3.3 \\
] $15-30]$ & 1.8 & 1.2 & 1.6 & 2.6 \\
$>30$ & 0.1 & 0.1 & 0.1 & 0.1 \\
Total & 100.0 & 100.0 & 100.0 & 100.0 \\
\hline
\end{tabular}

Source: Author.

or "excellent" accessibility, both in the first pedestrian profile $(31.36 \%)$ and in the second pedestrian profile $(30.54 \%)$. The quality of accessibility improves substantially when traveling by bicycle, where the values of "good" or "excellent" accessibility reach almost $80 \%$, while $17 \%$ have "weak" or "poor" accessibility to PCE. When considering traveling by car, more than $85 \%$ of the population has "excellent" accessibility, with only $2 \%$ of the population having poor or very poor accessibility to their PCE. Thus, we can say that the conditions of accessibility in Baixo Alentejo largely depend on the opportunity to access an individual motorized means to access their primary health unit.

Another conclusion relates to the differences in accessibility observed by the different age groups. In general, the older population has higher time distance values, resulting in worse accessibility conditions to PCE. These values are associated with the fact that in the Baixo Alentejo, the younger, school age people live in the main population centers, particularly in the county centers, while the older population lives outside the county's center, in less central areas and, in some cases, more isolated and distant from the PCE. 


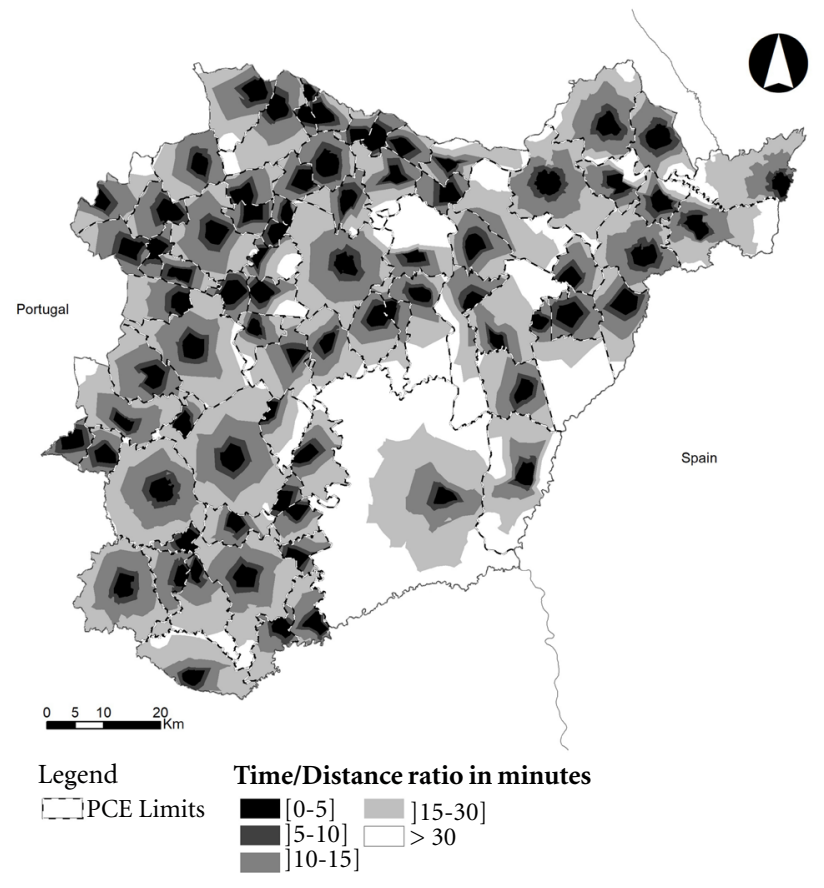

Figure 4. Profile on bicycle.

Source: Own development.

\section{Collaborations}

Work conception and design: C Freitas and NM Costa. Theoretical framework: C Freitas and NM Costa. Selection of variables, collecting data, selecting variables, methodological implementation: C Freitas and NM Costa. Discussion of the results: C Freitas and NM Costa. Conclusions: C Freitas and NM Costa.

\section{References}

1. Palma P, Marques da Costa E, Marques da Costa N. Disparidades regionais no acesso aos serviços de saúde em territórios de baixa densidade: os casos do Alentejo (Portugal) e Navarra (Espanha). In: Ribeiro Soares B, Marques da Costa N, Lima SC, Marques da Costa E, organizadores. Construindo Cidades Saudáveis: utopias e práticas. Uberlândia: Ed. Assis; 2017. p. 449-483.

2. Marques da Costa E, Palma P, Marques da Costa N. Regional Disparities of SGI Provision. In: Fassmann $\mathrm{H}$, Rauhut D, Marques da Costa E, Humer A, editors. Services of General Interest - European Perspectives and National Insights. Vienna: V e R Verlag; 2015. p. 91121.

3. Dummer T. Health geography: supporting public health policy and planning. CMAJ 2008; 178(9):11771180.

4. Higgs G. The role of GIS for health utilization studies: literature review. Health Services and Outcomes Research Methodology 2009; 9(2):84-99.

5. Hägerstraand T. What about people in regional science? Papers in Regional Science 1970; 24(1):6-21. 
6. Wang F, Luo W. Assessing spatial and nonspatial factors for healthcare access: towards an integrated approach to defining health professional shortage areas. Health Place 2005; 11: 131-146.

7. Cyr M, Etchin A, Guthrie B,Benneyan J. Access to specialty healthcare in urban versus rural US populations: a systematic literature review. BMC Health Serv Res 2019; 19(1):974.

8. McGrail M.R. Spatial accessibility of primary health care utilising the two step floating catchment area method: an assessment of recent improvements. Int $J$ Health Geogr 2012; 11:50.

9. Kanuganti S, Kumar Sarkar A K, Singh AP. Evaluation of access to health care in rural areas using enhanced two-step floating catchment area (E2SFCA) method. Journal of Transport Geography 2016; 56:45-52.

10. European Forum for Geography and Statistics [Site on the Internet].1995 Jan-Mar [cited $2020 \mathrm{Fev}$ 25]:[about 24 p.]. Available from: https://www.efgs. info/geostat/

11. Aranha F, Figoli S. Geomarketing: Memórias de Viagem. Rio de Janeiro: FGV; 2001. (Documento eletrônico)

12. Weber J, Kuan M. Individual accessibility revisited: implications for geographical analysis in the twenty-first century. Geographical Analysis 2003; 35(4):341-353.

13. Allan A. Walking as a local transport modal choice in Adelaide. World Transport Policy \& Practice 2001; 7(2):43-50.

14. Apparicio P, Abdelmajid M., Riva M., Shearmur R. Comparing alternative approaches to measuring the geographical accessibility of urban health services: Distance types and aggregation error issues. Int $J$ Health Geogr 2008; 7(1):1-14.

15. Vale D. A Cidade e a Bicicleta: uma leitura analítica. Finisterra 2016; 51(103):45-66.

16. Marques da Costa N. Mobilidade e Transporte em Áreas Urbanas. O caso da Área Metropolitana de Lisboa [dissertação]. Lisboa: Universidade de Lisboa; 2007.

17. Figueira de Sousa J, Ferreira H, Fernandes A. Transportes Colectivos em Espaço Rural e Áreas de Baixa Densidade Urbana: Abordagens e Soluções. $1^{\circ}$ Congresso de Desenvolvimento Regional de Cabo Verde; 2009; p. 2562-258.

Paper submitted on 26/03/2020

Approved on 10/08/2020

Final version submitted on 12/08/2020

Chief editors: Maria Cecília de Souza Minayo, Romeu Gomes, Antônio Augusto Moura da Silva 